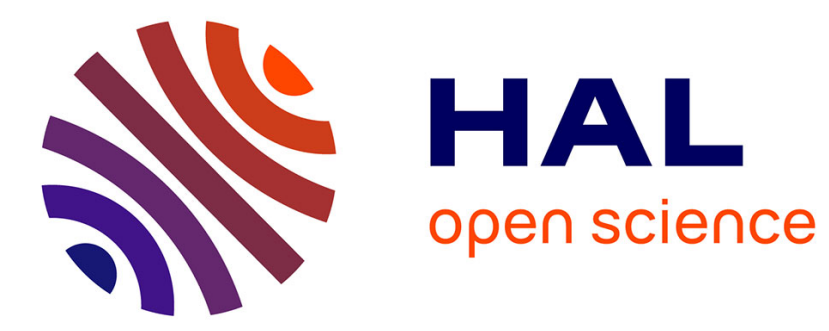

\title{
Contention and Discontent Surrounding Religion in Noughties' Austria
}

\author{
Jérôme Segal, Ian Mansfield
}

\section{To cite this version:}

Jérôme Segal, Ian Mansfield. Contention and Discontent Surrounding Religion in Noughties' Austria. Austrian Studies, 2011, The Austrian Noughties: Texts, Films, Debates, 19, pp.52-67. hal-01525512

\section{HAL Id: hal-01525512 \\ https://hal.science/hal-01525512}

Submitted on 22 May 2017

HAL is a multi-disciplinary open access archive for the deposit and dissemination of scientific research documents, whether they are published or not. The documents may come from teaching and research institutions in France or abroad, or from public or private research centers.
L'archive ouverte pluridisciplinaire HAL, est destinée au dépôt et à la diffusion de documents scientifiques de niveau recherche, publiés ou non, émanant des établissements d'enseignement et de recherche français ou étrangers, des laboratoires publics ou privés. 


\section{Contention and Discontent Surrounding Religion in Austria}

How the 'noughties' reveal the risks of having religion as an element of Austrian identity

Jérôme Segal and Ian Mansfield

Religion appeared as a common thread in many of the social controversies and conflicts in Austria during the 'noughties'. These conflicts were discussed in the public sphere, but did not play the role they had in the constitution of modern states, as has been shown more generally by Habermas and more recent scholars. ${ }^{1}$ A series of questions emerged over this period concerning, for example, the extent to which Catholicism was still part of Austrian identity, or whether the effects of migration and globalisation had weakened this sense of affiliation.

Religious topics have cropped up throughout Europe, e.g. the ban on minarets in Switzerland, the prohibition of burqas and niqabs in France and Belgium, or the European Court verdict on displaying the cross in the classroom in Italy. These subjects have readily been taken up in Austria and formed the focal points of public and media discussion, although Austria itself has not yet taken an official stance on these subjects. Similarly, Austria has not been spared from the scandals concerning child abuse in the Catholic church and in private and public institutions. In other words, general European trends have not passed by Austria.

Although these topics were openly discussed, a closer study of the 'noughties' shows that these phenomena are symptoms of a deeper unease with religion below the surface of Austrian society. Indeed, this unease has been a constant in the relations between the Austrian state and the Jewish community, as the presence of Judaism or even Jewish culture is a continuous reminder of guilt in the past. At the end of the 'noughties, religion appears to serve as a theatrical backdrop to political events of no relevance whatever to matters of faith. A case in point was the prominent extreme rightist politician Jörg Haider's death in a car accident in 2008. The aftermath of the accident, the funeral and remembrance ceremonies became something of a pseudo-religious cult with nation-wide mourning, thousands of candles and religious memorial services. ${ }^{2}$ The conspiracy theories surrounding Haider's death even mythologised him as a kind of martyr figure. A similar theatrical gesture was made by Haider's successor as party leader, Heinz-Christian Strache, during an election rally in Styria in 2009 when he held up a crucifix to symbolise his championship of Christian values against 
Muslim ones and as a reminder of Austria's historical role as a bulwark against Turkish/Islamic incursions in the seventeenth century.

After reviewing the status quo at the beginning of the 'noughties' and the historical development up to then, this paper will discuss the issue of controversies and conflicts concerning the different religions in the 'noughties'. A third and final section will deal with the legacy of the 'noughties', present a possible outlook on the future and offer conclusions as to the position of religion in society.

\section{$\underline{\text { I - Tolerance or apathy? The acceptance of religions }}$}

For centuries, pre-republican Austria was regarded as the bulwark of the counterreformation and the political and social doctrines advocated by the Catholic church. The Habsburgs, as ruling dynasty, also had close personal and symbolic ties to the Catholic church. But the Austro-Hungarian Monarchy was a multi-ethnic state with diverse religions, with which arrangements had to be found. The first step in this direction was the Tolerance Patent of 1781, which recognised the Protestant churches and the Greek Orthodox church. A tolerance patent for the Jews followed a year later. Legal recognition of religious communities goes back to a Constitutional Law of 21 December 1867, conceding recognised churches or religious communities certain basic rights and privileges. However, how such a recognition was to be obtained was only laid down in the Recognition Act of 1874, which stipulated that every religious community was to be recognised in a law of its own. The first community to be recognised according to this law was the Old Catholic church. In 1890, the so-called 'Israelite Act' ('Israelitengesetz') put relations between the state and the Jewish communities on a legal footing. It was not until the occupation of Bosnia-Herzegovina in 1878 and its annexation in 1908 that Austria-Hungary acquired a sizeable Muslim population $(600,000$ in Bosnia as against 1,281 in the core territories of the Monarchy, including 889 in Vienna alone). This was then reflected in the 'Islam Act' of 1912, recognising Muslims according to the Hanafi rite. Due its association with Bosnia-Herzegovina and the Habsburg past, as a religion, Islam was long regarded positively, even nostalgically in Austria.

Following the disintegration of the Monarchy and the collapse of the dynasty in November 1918, a tight partnership developed between the Catholic Church and its only remaining political patron, the Christian Social Party. This bond was cemented when Prelate Ignaz 
Seipel became official party leader after 1920. As Federal Chancellor (1922-1924 and again 1926-1929), Seipel sought to assert Catholic cultural values and social ideals in society in opposition to the anticlerical stance of his opponents, the Social Democrats and Communists, who perceived a diabolical union between the church and the state. This is the great 'divide' between the Right and the Left, characterising the politics of the First Republic. The Christian Social Party was supported by a multi-tiered system of associations and organisations, many of which were associated with the Catholic church. Indeed, in 1934 the headquarters of 93 Catholic societies or associations were located in Vienna alone and provided the party with officials and candidates, many of whom were priests. ${ }^{3}$ The Cartellverband for universityeducated political and administrative elites was and is particularly noteworthy. The partnership between the church and the Christian Social Party was vividly reflected in the Austrian Catholic Congress ('Katholikentag') of September 1933, at which the incumbent chancellor, Engelbert Dollfuß, declared his intention to create an authoritarian corporate state ('Ständestaat'), inspired by the Italian fascist model. The Austrofascist corporate regime regarded itself as a Catholic-German state, based on Catholic social teachings, in particular the encyclicals Rerum Novarum (1891) and Quadragesimo anno (1931), and defending a Catholic West, as, for example, against the Turks in 1683 (an idea frequently reiterated during the 'noughties', as will be seen). Consequently, a new concordat was concluded between Austria and the Holy See in 1933. The union of Catholicism and state was complete, so much so that the protestant minority feared a new Counter-Reformation due to the harassment they were subjected to. ${ }^{4}$ For their part, as Friedrich Heer states, the Austrian Protestants tended to view themselves as ethnic Germans and to advocate Austria's union with Germany. ${ }^{5}$

The corporate state was ended very abruptly by the invasion by German troops in March 1938. The Anschluss was greeted by the leaders of both the Catholic and Protestant churches, presumably with hopes of restoring cohesion in society and reunifying and strengthening the position of German-speaking peoples in Europe. The persecution of both churches began immediately, although Cardinal Innitzer, the primate of the Catholic church in Austria had had a recommendation to vote for the Anschluss and Hitler in the plebiscite of 10 April 1938 read from the pulpit. ${ }^{6}$ The post-war relations between the state and the two Christian religions were deeply marked by the conflicts of the First Republic.

Today, recognition as a state religion guarantees certain basic rights: the right to religious exercise in public; the right to exclusivity (protection of names with a religious background, claim to exclusive religious care by members of the same confession); autonomous 
organisation and administration of internal affairs; protection of institutions, foundations and funds against secularisation; the right to set up confessional private schools; the right to teach religious lessons at public schools. Currently, 15 religious communities are recognised in Austria. ${ }^{7}$ All these religious communities enjoy heightened protection against penal offences, and contempt for religious teachings or disturbing religious observation is punishable by law. However, as will be elaborated in greater depth later, some complex issues have emerged, as a number of Muslim and Jewish religious communities do not feel represented by the officially recognised organisations. The 'Islamische Glaubensgemeinschaft in Österreich' (the Islamic community in Austria, IGGiÖ) was awarded the status of a public body in 1979 and entrusted with the organisation of Islamic religious teaching three years later. It is the only officially recognised Islamic organisation in Austria and is largely dominated by Sunnites, but purports also to represent Shiites. The Alevis in Austria regard themselves as Muslims, but are not even acknowledged as such by the official representation, so they have applied for recognition as a separate religious community. Similarly, a number of Jewish communities do not feel represented by the official 'Kultusgemeinde', including the orthodox group Chabad-Lubavitch and the liberal community Or Chadasch.

On 10 January 1998, the Recognition Act was amended to the Religious Communities Act, stipulating as the necessary conditions for recognition the existence of the religious association for at least twenty years in Austria and for at least ten years as a registered religious community and a minimum number of two adherents per thousand members of the Austrian population. In addition to the officially recognised religions, the concept of registered religious communities had also been introduced in 1997. These enjoy a slightly different legal status. Whereas they are legal entities of their own, they do not possess the same privileges as recognised religious communities. Two such groups are the Bahai religious community (760 members) and the Federation of Evangelical Communities in Austria (2,108 members). Religious communities not fulfilling the conditions for recognised religions or registered religious communities can be constituted as societies pursuant to the law of association.

Associations are not covered by the Recognition Act. This is the case with confessional Non-Governmental Organisations, which play a large and very visible role in Civil Society, specifically in the provision of social services. Today, as in the 'noughties', the largest Roman Catholic NGO is the Caritas, which covers all areas of social work from mother-and-child homes to care and nursing for older persons, but places a special focus on running homes and 
performing social work for the homeless. Its evangelical counterpart is the Diakonie, which is smaller by comparison because of the correspondingly smaller size of the Protestant community and is especially known for its work with disabled persons in the federal provinces. It also runs Amber-Med, an organisation offering free medical care to asylum seekers and persons without social insurance. Both Christian relief organisations are largely financed by donations. During the 'noughties', the heads of both these charities were often very vociferous in their criticism of everyday politics when issues such as migration, social care, family policies, asylum and deportation, or even budget allocation, were at the forefront of public discourse. In general, the Protestant churches tend to evince more liberal and progressive social policy stances than their Catholic counterparts as could be seen, for instance, in the election campaign by the former Protestant Bishop Gertraud Knoll in 1998 and her subsequent political career in the Green and Social Democratic parties.

For its part, the Jewish community in Vienna runs the so-called Sanatorium MaimonidesZentrum, which caters especially to older people and combines many different facilities under one roof: nursing wards, an outpatients' clinic and a day-care centre. It also offers an intergenerational approach, with a kindergarten, a school and sports facilities being housed on the same premises. In addition, there is the psycho-social centre ESRA, which, after originally treating victims of the Holocaust and their relatives, now sees its task in looking after all severely traumatised persons. As the last group of social service providers and an umbrella organisation, the Islamic community in Austria has run its own visiting and social services since 2000, the reason being that the family and social changes occasioned by migration no longer guarantee nursing care, for instance, by family members. The community's programme currently covers the following areas: the provision of a continuous visiting and social service in hospitals; a documentation of the special situation and needs of Muslim patients in health and social facilities; the expansion of the infrastructure for Muslim patients in hospitals; preparation of information material for Muslim and non-Muslim personnel in the social and health sectors; training courses for patients, relatives and medical staff; and promotion of inter-confessional co-ordination in the field of hospital pastoral care. ${ }^{8}$ In the field of education, the religious communities are responsible for the training and appointment of religious teachers, but the teachers are paid by the state. In the 'noughties', a discussion emerged as to whether religious symbols, in this context the crucifix, should be displayed in the classroom. The present legal situation is that in schools where there is mandatory religious instruction and the majority of the class is Christian, a crucifix is to be placed in the classroom 
(crucifixes can also be found in courtrooms, but up to now they have not been a bone of contention).

As regards Judaism, its rare visibility in the public sphere (usually in the form of kippas) does not attract much attention. There has been great respect for any expression of the Jewish religion for historical reasons: on the one hand, the long tradition of a Jewish community in Vienna (recognised in 1890, as mentioned above) and also out of a sense of guilt due to the active participation of Austrians in the expulsion and murder of the Jews following the Anschluss. Jewish matters are handled with considerable sensitivity, self-consciousness and sometimes embarrassment, as the image of the country might suffer from perceived antiSemitism. Nonetheless, latent anti-Semitism in Austria should not be underrated. Jörg Haider, for example, played on anti-Semitic sentiments in Austria when he asked the rhetorical question as to how someone with the first name of 'Ariel' (referring to Ariel Muzicant, President of the 'Israelitische Kultusgemeinde') could have so much muck in his past. ${ }^{9}$ Another instance of this embarrassment might be the Waldheim affair in the mid-1980s, when there were veiled allusions in the press to the 'East Coast' of the USA, meaning de facto worldwide Jewish financial hegemony. ${ }^{10}$ However, the damage that could be contained in the case of the Waldheim affair was to reappear with a vengeance with both the Jews and the Muslims in the 'noughties'.

Islam did not offer any target for antagonism before the 'noughties' and 9/11 at the latest. The situation changed as Islam came to be perceived as almost synonymous with the phenomenon of worldwide terrorism and because Muslims (particularly from Turkey) represented the majority immigrant group. Between 1971, when the first figures were recorded, and the last census in 2001, the Muslim population of Austria grew from 22,267 (or $0.3 \%$ of the total population) to $338,988(4.2 \%)$, i.e. over 15 times the original figure within 30 years. The increase is largely due to new births, as Muslim women tend to have one child more on average than other Austrian women, but also to family reunification. ${ }^{11}$ The enormous growth in the Muslim population started to become visible in the 2000s, particularly in the increase of head scarves to be seen in the public sphere and the ghettoisation of certain districts of Vienna. The Vienna Institute of Demography of the Austrian Academy of Sciences has drawn up different scenarios for the future proportions of religions in Austria. For the year 2051, a Muslim percentage of 14 to $18 \%$ has been calculated, whereas that of Roman Catholics would drop from $75 \%$ in 2001 to under $50 \%$ and that of persons without 
religious affiliation rise to up to $34 \% .^{12}$ This has led right-wing circles to talk of the gradual Islamisation of Austria and the corrosion of Austrian cultural values.

\section{$\underline{\text { II }- \text { Religion and controversy }}$}

It would be too much to assert that controversies surrounding religion only emerged in the 'noughties', but even if more distance might be required, it seems characteristic of the period that many religions - not only the quasi-hegemonic Catholic church - were at the core of heated discussions, whereas Catholicism was less present in the public space. Corpus Christi processions and public first communions, which were still very frequent twenty years ago, have become less visible, even in the countryside, where developments tends to be slower.

The Viennese underground and shopping malls might be considered natural extensions of the public sphere, marked in the 'noughties' by the progressive proliferation of free newspapers distributed in stands at almost all traffic junctions. In this environment, the representatives of the Jehovah's Witnesses constitute fixed pillars in the daily lives of all users of the public transportation system ('Öffis' in the vernacular). They stand in all the main halls or important underground stations, flogging their journal, Watch Tower, published in as many languages as those spoken in Vienna. Regularly, cases have been brought against the Jehovah's Witnesses, be it following the publication of books or articles in the newspapers. In 2006, for example, many dailies reported that parents of this denomination had allowed their son to bleed to death because their doctrine explicitly forbids blood transfusion. ${ }^{13}$ Despite their poor public image, after long proceedings before different national courts, commencing as early as 1978, the European Court of Human Rights condemned the Austrian State on 31 July 2008 for not recognising the Jehovah's Witnesses as a religious community. They therefore became the fifteenth recognised religion on 7 May 2009. As was stated in the verdict, the Jehovah's Witnesses fulfilled the conditions of the Religious Communities Act mentioned earlier. They just managed to reach the strict requirement of two members per thousand of the population (as of March 2009, this newly recognised religion numbered 23,000 adherents). ${ }^{14}$

Looking back over the 'noughties', the main controversies linked to religion definitely concerned the Catholic church, with an disproportional number of cases relating to child abuse or close affiliations to ultra-conservative splinter groups. The Austrian Catholic church 
had already made international headlines in the mid-1990s with the case of the primate of the Austrian church, Hans Hermann Groër. ${ }^{15}$ In 1995, this 75-year-old Cardinal had been accused of sexual abuse committed 20 years earlier. In a typically 'diplomatic' reaction, the Vatican refused to initiate an investigation and appointed Bishop Christoph Schönborn as Archbishop co-adjudicator, intended to replace Groër in the following months. Schönborn initially stayed loyal to Groër, comparing, in a controversial statement, the attacks on Groër to those made by the Nazis on clerics during the NS period. Within a month, the Groër affair caused 5,500 Austrians to leave the church and eventually gave rise to a civic movement, 'Wir sind Kirche' (We are Church). ${ }^{16}$ This movement demanded, among other things, the relinquishment of the requirement of celibacy for the priesthood and a more progressive attitude towards sexuality, including homosexuality. In July 1995, more than 500,000 supporters signed a petition in favour of this movement, which then expanded. A federation entitled 'International Movement We are Church', IMWAC, was established in 1996 and enabled expansions to Germany and a few other countries. ${ }^{17}$ In 2002, the organisation appointed seven women as priests and, the following year, a woman became the first female bishop (of course, not acknowledged by the official church). The protest movement played a significant role in the case surrounding the ultra-conservative Bishop Kurt Krenn, who ran the priest's seminary in St. Pölten, Lower Austria. In his seminary, up to 40,000 files relating to child pornography were found by the police, an affair that Krenn dismissed as a 'childish prank' ('Bubendummheit'). ${ }^{18}$

Besides these well-known cases, the 'noughties' were also marked by the appointment of very conservative clerics. When Pope John Paul II urged Krenn to retire, it was Klaus Küng from the secretive and traditionalist Opus Dei movement who was appointed his successor as Bishop of St. Pölten. In 2006, he defended corporal punishment in a journal interview. ${ }^{19}$ Whereas Opus Dei was rather discrete at the end of the twentieth century, it heightened its profile in the 'noughties', even if critical media like Falter or the Standard continued to equate the movement with a sect. ${ }^{20}$

These controversies centring on the Catholic church differed from those concerning the relationship with Judaism, which is still covered by a sombre shroud from the past, a consequence of the difficult process of coming to terms with the past (in German, the wellknown concept of 'Vergangenheitsbewältigung'). At least two important issues dominated the 'noughties': restitution of property, and the restoration and maintenance of Jewish cemeteries. When the extreme right was in coalition government with the conservative party (2000-2006), 
the Minister of Education and Culture, Elisabeth Gehrer, had to deal with the restitution of world-famous paintings. The most emblematic case was probably the portrait Adele BlochBauer I, painted by Gustav Klimt in 1907. The affair followed the coming into effect of the Federal 'Art Restitution Act' ('Kunstrückgabegesetz'), which was passed in December 1998, after a painting by Egon Schiele belonging to the Leopold Collection had been confiscated in New York. The law empowers public museums to return works of art which were looted or purchased for ridiculous prices from Jews fleeing the Third Reich, and then sold to art merchants. 'Adele', as the Austrians nickname the painting, appeared on the front pages of newspapers in 2000, when a Klimt retrospective was held in the Belvedere. When the painting was restored to its heirs, in 2006, Elisabeth Gehrer lamented instead of rejoicing that justice had finally been done: 'Es ist natürlich sehr schade um die Bilder' ('it is, of course, a great pity about the pictures'). ${ }^{21}$ The President of the 'Israelitische Kultusgemeinde' (IKG), Ariel Muzicant, followed all these cases closely and it was in the 'noughties' that the IKG started to become a nuisance to the Austrian authorities, organizing protests, for example, against the Leopold Museum. As it is an institution run by a foundation (the 'Leopoldstiftung'), and not a federal museum, the Restitution Act did not apply and a spectacular demonstration took place. To mark simultaneously the seventieth anniversary of the 'Kristallnacht', members of the IKG obstructed access to the Leopold Museum for a short time on 9 November 2008 with barrier tapes labelled 'Art Crime Scene'.

It is interesting to note that the central issue of contention between the Austrian state and the Jewish community concerns the restitution of property, which, in itself, has nothing to do with religion. Indeed, in a book on religion in Austria published in 2005, one of the only two reports given on public discussion forums was devoted entirely to the issue of restitution. ${ }^{22}$ In fact, a general settlement, the 'Washington Agreement', was signed between the Austrian State, the US authorities and the IKG in January 2001. The goal was to close the remaining gaps in the Restitution Act and the core part of this agreement was the General Settlement Fund, endowed with Austrian contributions totalling 210 million US dollars. The Jewish cemeteries, which are of paramount importance for practising Jews, were supposed to be restored, but it took until 2010 for a solution to be found (the federal state and the provinces kept passing the buck to and fro). When employees of the US Embassy decided in July 2007 to renovate the Währing Cemetery in Vienna, together with representatives of the Green Party, the apathy of the Austrian government came under harsh criticism. Lack of tact and diplomacy was probably a characteristic of this time, when the Austrian authorities started to 
support commemorations and events linked to bygone Jewish culture (for instance, the seventieth anniversary of the Anschluss), rather than its lively contemporary manifestations (Jewish theatre, Jewish film festival etc.). ${ }^{23}$

For the Austrian population, the most visible changes concerning religion in the 'noughties' probably relate to Islam. As has been mentioned earlier, the Muslim population grew rapidly in the 'noughties'. Many tensions have appeared in Austrian society and the ultra-rightist party, the Freedom Party of Austria (FPÖ), has seized these opportunities to gain popularity, using, for instance, slogans like 'Daham statt Islam' (Home, not Islam) for the 2006 parliamentary elections. Indignation was caused in Vienna in 2005 by Feridun Zaimoğlu's installation entitled Kanak Attack - Die dritte Türkenbelagerung (The third siege of the Turks) at the Museumsquartier. The artist covered the façade of the Kunsthalle with Turkish flags, to echo the 1683 Siege of Vienna. Many surveys have also regularly been published in the media on the alleged difficulty of reconciling Islam and traditional Austrian society. A study commissioned by the Interior Ministry in 2006 stated, for instance, that about forty per cent of the Austrian population had a negative attitude towards the Muslim community, probably as a consequence of an ongoing hate discourse in dailies such as the Kronen Zeitung. ${ }^{24}$ Forced marriages, honour crimes or the issue of head scarves, niqabs and burqas are regularly reported and heatedly discussed, for instance when Turkey's possible accession to the EU is mentioned, even though there are hardly any niqabs and burqas in Austria. $^{25}$

Moreover, Islamic religious teachers are also attacked, and these polemics often rely on survey findings claiming, for instance, that these teachers show more allegiance to the Koran than to the Austrian constitution. A study carried out among 330 Islamic religion teachers in 2007 and enquiring about issues concerning democracy and the rule of law produced 'disastrous' results, as its author, Mouhanad Khorchide, commented. ${ }^{26}$ Asked if they rejected democracy because it was incompatible with Islam, $21.9 \%$ of the 210 respondents answered positively. Asked if they rejected the Declaration of Human Rights because it was incompatible with Islam, 27.1\% also replied yes. Asked if they would understand it if Muslims apostatising from Islam should be sentenced to death, even 18.2\% agreed. Asked if they saw a contradiction between being a Muslim and a European, 28.4\% consented. Khorchide came to the conclusion that about one fifth of the Islamic religion teachers held 'fanatical attitudes'. The study was published as a book and triggered off heated discussion. ${ }^{27}$ The journalist Stefan Apfl, for example, expressed concern about the fact that Austria might 
be serving as a refuge for fundamentalist religion teachers like Amir Zaidan who had been forbidden to teach religion in Germany. This man is reported to have been a leading figure in religion teacher training in Austria since 2003. Another case concerned Adnan Ibrahim. The well-known imam from Palestine has frequently been suspected of anti-Semitic agitation in the past. In a Friday sermon towards the end of the Gaza War, Ibrahim praised the Hamas and termed Israel a 'beast'. Significantly, Ibrahim has been training Islamic religion teachers at the Islamic Academy for years and could not be suspended by the IGGiÖ because the imam was only responsible to the community in his mosque which had elected him. ${ }^{28}$

A further problem was posed by the fact that until 2003 there was only one school inspector for Islamic religion teachers, the President of the IGGiÖ, Anas Shakfeh. It was only after he had admitted that he had no time to inspect the 2,700 locations where Islamic religion was taught that additional inspectors were hired. Until that juncture, Islamic religion teachers had not been supervised for twenty years. In 2009, after publishing an article in the Standard harshly criticising the IGGiÖ and its unprofessional, backward-looking and communitarian organisation of Islamic religion teaching, Aly El Ghoubashy was summarily dismissed from his teaching post by Anas Shakfeh within 24 hours. ${ }^{29}$ Two years later, to improve the situation a private educational institution was founded in Wien-Liesing. It trains Islamic religion teachers in a more academic, professional and systematic way and run by a foundation bearing Anas Shakfeh's name. ${ }^{30}$ Shakfeh has also since been awarded the Golden Cross of Merit of the City of Vienna.

Despite this award by the Austrian authorities, Shakfeh remains a controversial figure. Following, for example, the Gaza flotilla raid in June 2010, a demonstration supported by the IGGiÖ took place in Vienna to protest against the Israeli operation. Banners were waved equating the Star of David to the swastika and reading 'Hitler wake up'. Muzicant and leading figures in the Jewish community condemned this demonstration, which for Shafkeh was a legitimate expression of criticism of Israeli policy. ${ }^{31}$

This poisonous atmosphere spread over the 'noughties', with the situation seeming to escalate at the end of the period. This concerns particularly the relationships with Islam, but also the two other monotheistic religions. In 2010, this development has led to a legacy which is still difficult to describe, as we cannot yet stand back to assess the period from sufficient distance. 


\section{III - The legacy of the 'noughties'}

As far as can be judged in 2011, although Austria was dominated by common European or worldwide trends, the country has its own specific legacy of the 'noughties'. Against this backdrop, the status and role of Islam in Austrian society has probably been the most hotly debated issue. Even if the aftermath of 9/11 took much the same form as in other European countries, e.g. a general suspicion of anyone or anything Islamic, many observers notice underlying changes. Asked about developments concerning Islam in Austria during the 'noughties', Tarafa Baghajati, the head of the 'Initiative of Austrian Muslims' (a kind of unofficial sub-section of the IGGiÖ), explained that a general paradigm shift occurred in the 'noughties' in the discourse about migration and migrants. ${ }^{32}$ Whereas the discussion used to centre on migrants from all different countries of origin (and especially on those from SouthEastern Europe and Turkey), it now relates primarily to migrants of Muslim origin and their children and grandchildren second, often with Austrian citizenship. In his view, whereas antiSemitism is taboo, a sense of community has been formed among some Austrians, using ignorance and fear of or even hatred towards Muslims as its rallying cry. Aversion towards migrants as a whole has given way to religious hostility and fanaticism, the latter based not on religious feelings, but on prejudices and stereotypes. In a collection on the topics of integration, racism and the world economic crisis, Baghajati opens by saying:

Während ins allgemeine Bewusstsein nur schwer durchdringt, dass Österreich de facto ein Zuwanderungsland ist, werden unter dem Deckmantel des Integrationsthemas vor allem Fragen der Kompatibilität behandelt. Denn die 'Ausländerthematik' verlagert sich zunehmend in Richtung der Themen 'Islam und Muslime': Demokratiebewusstsein, Werte wie Rede- und Meinungsfreiheit oder das Bekenntnis zum säkularen Rechtsstaat stehen auf dem Prüfstand. Die zunehmende Sichtbarkeit von Muslimen wirft Fragen auf, die von Voraussagen der zukünftigen demographischen Entwicklung über den Bau von Moscheen bis hin zum nachbarschaftlichen Zusammenleben reichen. ${ }^{33}$

Baghajati goes on to press for a distinction to be made between Islamophobia and hostility towards Islam ('Islamfeindlichkeit'). The former consists of a diffuse mass of irrational sensations and prejudices, whereas the latter represents a response to political agitation and is 
steered by (often extreme right-wing) populists. People suffering from e.g. arachnophobia cannot be held responsible, they are even victims of their disease, whereas racists are themselves responsible for the views they hold. Nonetheless, Islamophobia is a concept frequently used in academic discourse as evidenced in a book recently edited by John Bunzl and Farid Hafez. ${ }^{34}$ In one of the articles in this collection, Hafez deals with the complex relationship between the FPÖ and Islam. In a 2008 position paper of the party he refers to, Islam is initially viewed surprisingly positively, as long as ethnics groups are not mingled, the alleged superiority of Western culture to foreign ones is not challenged and these cultures are restricted to foreign countries. However as soon as the discussion moves to the issue of Islamic fundamentalism and the alleged 'Islamisation of Europe', the tone becomes harsher. Fundamentalism and Islam as a religion are thrown together into the same pot:

'Der islamische Fundamentalismus stellt für die europäischen Gesellschaften wegen der muslimischen Massenzuwanderung eine immer größer werdende Bedrohung dar. (...) Es muß geklärt werden, in welcher Weise muslimische Traditionen mit dem europäischen Demokratie- und Grundrechtsverständnis vereinbar sind. Es ist unerlässlich - von den in Österreich lebenden Moslems Stellungnahmen zum religiös motivierten Extremismus und Terrorismus zu verlangen. $^{35}$

Two other authors in the same collection analyzed the presentation of Islam in Austrian schoolbooks and made interesting observations. The stereotype is reproduced in history books, for instance, that Islam is a bellicose religion, whereas Christianity is a peaceful one when it is stated that the rapid spread of Islam was due to military conquest and not perhaps to any innate power of conviction the religion might have. ${ }^{36}$ This analysis partly explains how the poor image of Islam is passed on to the next generation in Austria.

A central image concern also affects the Catholic church, resulting in the mass exodus of its members since at least the 1960s. According to the Concordat, registered members of the Catholic church must pay an annual church tax, which is collected by the church itself (as opposed to the state in Germany). This church tax was introduced during the Third Reich as a means to induce believers to leave the church, but has had a delayed effect and has not been abolished since. It is taken as an excuse by many people of otherwise religious conviction to leave the church for financial reasons. The scandals involving the church in the 'noughties', particularly the incidences of child abuse, have reinforced and increased this trend. In turn, the 
church has introduced a marketing strategy of cancelling outstanding tax debts in order to contain the damage (a 'Neustart-Aktion' offers complete debt cancellation in return for automatic debit transfer). As regards the major issue of child abuse, affecting most institutions involved with child care in Austria, the church has instituted an investigation committee to inquire into individual cases of child abuse and set up a compensation fund. Harsh criticism has been levelled against the committee because its members were appointed by the church and not institutions outside the church. The criticism has even gone so far as to claim that former victims are being judged by their former offenders (or their colleagues).

A particularly repugnant scandal during the 'noughties' concerned the notorious 'Fritzl affair' (in the spring of 2008), involving a man's twenty-four-year incestuous relationship with his daughter. The case attracted widespread international attention and scorn was heaped on Austria by tabloids in particular. This induced the chancellor of the time, Alfred Gusenbauer, to remark during his traditional 1 May speech that Austria would not be held hostage by an individual offender and would not allow its youth to be tainted with the stigma of a new original sin ('Wir werden nicht zulassen, dass irgendjemand glaubt, unserer Jugend eine neue Erbsünde andichten zu können.'). ${ }^{37}$ Although, traditionally, 1 May is a left-wing event and frequently used to announce progressive social policies, the chancellor could not help availing himself subconsciously of a Catholic diction simply because his background was a Catholic one. The topic addressed, namely the Fritzl affair, had nothing whatever to do with religion. This implies that Christian thinking may underpin the political analysis of some decision makers of whom this would not otherwise be expected. Even in the First Republic, it is striking how often politicians of both sides worded their political messages in terms of theological diction. Leading socialist figures such as Otto Bauer or Karl Renner, frequently refer to Socialism as the 'Holy Cause' ('Heilige Sache') or 'Salvation' ('Heil'). ${ }^{38}$

Conceivably, the role played by Austrians during the Holocaust explains the attitude of almost all Austrian politicians towards the Jewish community. After decades of stressing Austria's position as a victim (as on the initial Austrian Pavilion in Auschwitz), it is now generally accepted that Austria produced more than its proportion of perpetrators (Austrians constituted $8 \%$ of the population of the Reich, $14 \%$ of the SS, $40 \%$ of the concentration camp personnel and $70 \%$ of the logistical staff responsible for the Final Solution under Eichmann). ${ }^{39}$ So as to atone for this Austrian 'original sin', Austrian politicians, with the exception of the extreme right, seem to feel obliged to sponsor and support anything related to Jewishness, but preferably what is regarded as conservative, safe and anything but subversive. 
In journals such as David: Jüdische Kulturzeitschrift, the Illustrierte Neue Welt and, of course, Die Gemeinde (the official gazette of the IKG), the reader will find numerous largeformat, paid advertisements from the political parties and prominent individual politicians expressing best wishes on almost all Jewish feast days (Rosh Hashanah, Yom Kippur, Hanukkah and Pesach) or any anniversaries (sixtieth anniversary of Israel, one hundredth jubilee of Tel Aviv etc.). In view of the ongoing conflicts concerning restitution, the Austrian state seems to feel the need to be seen to be appeasing the Jewish community.

A major role in identifying, shaping and/or manipulating public opinion on religious and similar issues as well as politics in general is played by the print media, in Austria's case by the Kronen Zeitung in particular. This tabloid does not thematise the indirect support given to Jewish culture, rather it sticks to the restitution or cemeteries issues when dealing with the Jewish presence in Austria. Islam, however, is an omnipresent topic in almost every single issue. The Krone, as it is commonly known, has a circulation of 820,000 copies for a readership of 2.9 million in a country of 8.4 million inhabitants (i.e. one adult in two). This makes it the most widely read newspaper in the world and explains its enormous influence in Austria. Analysing the role played by this tabloid, Otto Friedrich, an editor of the Catholicoriented weekly Die Furche, came to the following conclusion:

Die Kronen Zeitung ist ein Medium, dem man zu mindestens eingestehen muss, dass es sehr wach ist für Strömungen und Meinungen in einem breiten Milieu. Und wenn sie glaubt, vermeintlich Strömungen entdeckt zu haben, diese dann durch ihre Berichterstattung zu verstärken versucht (...). Sie hat tendenziell einen kleinbürgerlichen Blickwinkel; dass sie eher nach rechts denn nach links blickt; dass sie im Zweifelsfall für law-and-order einsteht; dass sie im Zweifelsfall eher eine xenophobe Haltung vertritt. Und zwar in dem Sinne, dass sich Österreich vom Rest der Welt abschottet. Und all das betrifft natürlich auch die Darstellung des Islam. ${ }^{40}$

Whereas the topic of Islam is over-represented in this daily, the phenomenon of Islamophobia is rarely thematised. The Kronen Zeitung and the other media, of course, covered a climax in the diatribe against those regarded as 'alien' in Austria, which occurred in the night of 11/12 February 2009 - on the eve of the anniversary of the Austrian Civil War of 1934. The walls of the national memorial in the former concentration camp Mauthausen were smeared with extreme right-wing graffiti, reading: 'Was unseren Vätern der Jud, ist für uns 
die Moslembrut. Seid auf der Hut! 3. Weltkrieg - 8. Kreuzzug' (What the Jew was for our fathers, is the Muslim brood for us. Be on guard! $3^{\text {rd }}$ World War $-8^{\text {th }}$ Crusade). Indignation on the part of the press and the parties was promptly forthcoming and, whilst it was clear that the action had been planned, was approved in certain right-wing circles, and was not the work of a single perpetrator, the political leadership condemned the act of vandalism outright and distanced itself. Speaking on television, President Fischer deplored any form of anti-Semitism or xenophobia, but made no direct reference to Islamophobia or hostility to Islam, which might have been called for in the context. Although the sentiments expressed in the "writing on the wall' in no way reflect the views of the vast majority of Austrians, who will find them repugnant, it should be noted here that the lineage between the rhetoric used in some elections and the graffiti in Mauthausen with all that entails is a direct, not an indirect one.

Just as Mauthausen has become an accepted chapter in Austrian history, the development of religion in Austria during the 'noughties' has shown that Islam has still to be acknowledged as a constitutive element of society. As has been mentioned, Christianity still plays a leading role in the public sphere, both consciously and subconsciously, determining mentality. Judaism has obtained recognition and has returned to Austria, although nowhere near to the extent prevalent in the Monarchy, where Jews were simultaneously leading figures in cultural life and the victims of anti-Semitism.

The Austrian writer and journalist Robert Misik, a well-known public figure in leftist circles, published a book entitled Gott Behüte! (God Forbid!), answering the question as to why 'religion should be kept out of politics'. Deliberately misquoting Marx, Misik refers to religion not as the 'opium of the people', but as its stimulant ('Aufputschmittel'). ${ }^{41}$ In his view, religion is at the heart of many of the tensions manifest in society, even if it is not always apparent. Currently, religion in Austria is being instrumentalised for political ulterior motives, as if politicians, journalists and decision makers were not aware that society has largely become secular. As Charles Taylor puts it:

One understanding of secularity then is in terms of public spaces. These have allegedly been emptied of God, or of any reference to ultimate reality. Or taken from another side, as we function within various spheres of activity economic, political, cultural, educational, professional, recreational - the 
norms and principles we follow, the deliberations we engage in, generally don't refer us to God or to any religious belief; the considerations we act on are internal to the 'rationality' of each sphere - maximum gain within the economy, the greatest benefit to the greatest number in the political area and so on. This is in striking contrast to earlier periods, when Christian faith laid down authoritative prescriptions, often through the mouths of the clergy, which could not be easily ignored in any of these domains, such as the ban on usury, or the obligation to enforce orthodoxy. ${ }^{42}$

By contrast, when the possible Treaty establishing a Constitution for Europe was being worded, a heated discussion developed concerning whether there should be concrete reference in it Christian value and concept of God. As Cvijic and Zucca explain, the result was a compromise, the preamble only containing a vague reference to Europe's religious legacy. ${ }^{43}$ However, as the treaty has been abandoned, the issue as to whether Christian values should be included in a future European Constitution remains unsettled.

Currently, the accession of Turkey to the EU is being discussed, a touchy subject in the Austrian media. Against this backdrop, it is no longer the issue of Christian or Muslim values that needs to be discussed, but the fundamental relationship between church and state and whether the state should be purely secular in nature. One of the great achievements of the Enlightenment was the division between church and state. The controversies emerging in Austria during the 'noughties' have made it clear that the legacy of the Enlightenment, including the principles of pluralism, tolerance and humanism, is in jeopardy. Further studies of the 'noughties' might provide a reminder that religion has its place in the private rather than the public sphere. 
1 Jürgen Habermas, 'Religion in the Public Sphere', European Journal of Philosophy, 14 (2006), 1-25. Craig Calhoun, Habermas and the Public Sphere (Cambridge, MA: MIT Press, 1993).

2 Jérôme Segal, 'La mort de Jörg Haider - Pourquoi un culte national ?', Regards, 675 (2008), 28-29.

3 Gerhard Schultes, Der Reichbund der katholischen deutschen Jugend Österreichs. Entstehung und Geschichte, (Vienna: Wiener Dom-Verlag, 1967), p. 296.

$4 \quad$ Friedrich Heer, Der Kampf um die österreichische Identität (Vienna: Böhlau, 1981), p. 399.

$5 \quad$ Heer, chapter 10.

$6 \quad$ Gunter Lewy, The Catholic Church and Nazi Germany (New York: McGraw-Hill, 1964), p. 212.

7 Some sources, e.g. Religionen in Österreich (Bundeskanzleramt Österreich, http://tinyurl.com/rel-austria), indicate 14 recognised religions, disregarding one community (the 'Herrnhuter Brüdergemeine') that no longer has any members.

8 Martina Schmied, 'Islam in Österreich', in Islam, Islamismus und Islamischer Extremismus: Eine Einführung, ed. by Walter Feichtinger and Sibylle Wentker, (Vienna: Böhlau, 2008) pp. 189-206. 
9 'Ich verstehe überhaupt nicht, wie einer der Ariel heißt, so viel Dreck am Stecken haben kann' in K. Zellhofer, 'Jörg Haiders antisemitische Weltsicht', $N u, 7$ (2002), 3-6.

10 Harold H. Tittmann, The Waldheim Affair: Democracy Subverted (Dunkirk, NY: Frederick, 2000).

11 Anne Goujon, Vegard Skirbekk, Katrin Fliegenschnee, and Pawel Strzelecki: 'New Times, Old Beliefs: Projecting the future size of religions in Austria', Vienna Yearbook of Population Research, 2007, pp. 237-270 (especially Table 5 p. 250).

12 See Goujon et al. p. 257 (previous note).

13 Martina Schmidt, Ich war eine Zeugin Jehovas: Protokoll einer Verführung (Gütersloh: Gütersloher Verlagshaus, 2005).

14 Andrea Heigl, ‘Anerkennung vor dem Weltuntergang', Der Standard, 29 March 2009, p. 14.

15 Alan Cowell, ‘A National Church Faces a Challenge From Within', The New York Times, 24 June 1995, p. 13.

16 Peter Paul Kaspar, Das Schweigen des Kardinals und das Begehren des Kirchenvolks (Vienna: Kulturverlag, 1995).

17 See http://www.we-are-church.org, accessed 21 November 2010.

18 Gerhard Hofer, 'Heuchelei-Skandal, kein Sexskandal', Die Presse, 15 July 2004, p. 18. 
2006, p. 16.

20 See, for the $50^{\text {th }}$ anniversary of Opus Dei in Austria, n.a., 'Opus Dei feiert 50.

Geburtstag', Der Standard, 12 July 2007, p. 22.

21 in n.a., 'Gehrer: Republik gibt Bilder zurück', Der Standard, 17 January 2006, p. 14.

22 Günter Bischof, Religion in Austria (New Brunswick, NJ: Transaction-Publishers, 2005).

${ }^{23}$ Jérôme Segal, 'La culture juive en Autriche, absence de présence et présence de l'absence', Les Temps Modernes, 64 (2009), pp. 90-98.

24 Mathias Rohe, Perspektiven und Herausforderungen in der Integration muslimischer MitbürgerInnen in Österreich, (Vienna: Bundeministerium für Inneres, 2006).

25 Elisabeth Röhrlich, 'Halbmond, Kopftuch, Minarette - Zur Darstellung von TürkInnen in österreichischen Mediendiskurs', in Einwanderungsgesellschaften und kulturelle Vielfalt, ed. by G. Diendorfer, A. Rieber, B. Ziegler (Vienna: Studienverlag, 2010), pp. 21-32.

26 Stefan Apfl, 'Die Islamlehrer - Eine neue Studie enthüllt das autoritäre und undemokratische Weltbild muslimischer Religionslehrer' Der Falter, 28 January 2009, p. 5.

$27 \quad$ Mouhanad Khorchide, Der islamische Religionsunterricht zwischen Integration und Parallelgesellschaft - Einstellungen der islamischen ReligionslehrerInnen an öffentlichen Schulen (Wiesbaden: VS Verlag für Sozialwissenschaften / GWV Fachverlage GmbH, 2009). 
2009, p. 18 and 'Adnan Ibrahim wird weiterhin predigen', Der Standard, 16 January 2009, p. 24.

29 Aly El Ghoubashy, 'Lernen für das Leben in der Isolation', Der Standard, 24 February 2009, p. 26 and Maria Sterkl, 'Wir sind doch keine Kirche!', Der Standard, 26 February 2009, p. 17.

30 Nermin Ismail, 'Ein Vorzeigemodell für den Islamunterricht', Der Standard, 24 January 2011, p. 12.

31 n.a., 'Muzicant zeigt Veranstalter der Gaza-Demos an', Wiener Zeitung, 17 June 2010, p. 16.

32 Unpublished interview with Tarafa Baghajati by Jérôme Segal, 26 November 2010.

${ }^{33}$ 'Whereas it is only slowly penetrating general awareness that Austria is de facto an immigration country, it is mainly issues of compatibility that are being discussed under the cloak of integration. For the 'topic of foreigners' is increasingly shifting in the direction of the issues of 'Islam and Muslims'. Awareness of democracy, values such as freedom of speech and opinion or allegiance to the secular constitutional state are at stake. The growing visibility of Muslims poses questions extending from predictions about future demographic trends and the building of mosques to neighbourly co-existence.' (Unless otherwise stated, all translations are the authors' own.) Here, Tarafa Baghajati, 'Neuer Diskurs um Islam in Europa und Österreich', in Integration, Rassismen und Weltwirtschaftskrise, ed. by M. Oberlechner and G. Hetfleisch (Vienna: Braumüller Universitäts-Verlagsbuchhandlung, 2010), pp. 265-283 (p. 265). 

2009).

35 'Due to mass Muslim immigration, Islamic fundamentalism constitutes a growing threat to European societies. (...) It must be clarified to what extent Muslim traditions are compatible with the European interpretation of democracy and fundamental rights. It is indispensable to demand statements on religiously motivated extremism and terrorism from the Moslems living in Austria' in Bunzl and Hafez, pp. 111-112.

36 Marianne Pratl, 'Analyse der Schulbücher' in Bunzl and Hafez, 63-87, p. 64.

37 Alfred Gusenbauer, 1 May speech, as quoted in n.a., 'Gusenbauer und die Erbsünde', Profil, 3 May 2008, p. 24.

$38 \quad$ Heer, chapter 9, here p. 325 and 343.

39 David Art, The Politics of the Nazi Past in Germany and Austria (Cambridge: Cambridge University Press, 2005), p. 43.

40 'It must at least be conceded that the Kronen Zeitung is a medium that is very alert to trends and opinions in a broad milieu. When it believes it has discovered a trend, it endeavours to reinforce it by its coverage (...). It tends to evince the 'little man's' perspective, i.e. it looks to the right rather than the left; in case of doubt it stands for law and order and takes a xenophobic stance, xenophobic in the sense that Austria cuts itself off from the rest of the world. All of this, of course, also affects the presentation of Islam', in Alexander Osman, Darstellung des Islam und der MuslimInnen in Österreichischen Tageszeitungen: Eine qualitative Untersuchung ausgewählter JournalistInnen, (unpublished MA thesis, University of Vienna, 2009), p. 78. 
müssen (Vienna: Ueberreuter, 2008), p. 135.

42 Charles Taylor, A Secular Age (Cambridge, MA: Belknap Press, 2007), p. 2. See also Woran glaubt Europa? Religion und politische Kultur im neuen Europa, ed. by Krzysztof Michalski (Vienna: Passagen Verlag, 2007).

43 Srdjan Cvijic and Lorenzo Zucca, 'Does the European Constitution need Christian Values?', Oxford Journal of Legal Studies, 24 (2004), 739-748. 